\title{
Facile Method to Synthesize N-Graphene Nano Sheets
}

\author{
RIKSON SIBURIAN ${ }^{1,4 *}$, DEWIRATIH ${ }^{2 *}$, ANDIAYANI ${ }^{1}$, SABARMIN PERANGIN-ANGIN ${ }^{1}$, \\ HELMINA SEMBIRING ${ }^{1}$, HERLINCE SIHOTANG ${ }^{1}$, SAUR LUMBAN RAJA ${ }^{1}$, MINTO \\ SUPENO ${ }^{1}$, NURHAIDA PASARIBU ${ }^{1}$, CRISTINA SIMANJUNTAK ${ }^{2}$ and SRI PRATIWI ${ }^{3}$
}

\author{
'Department of Chemistry, Universitas Sumatera Utara-Medan, Indonesia. \\ ${ }^{2}$ Post-Graduate School-Department of Chemistry, Universitas Sumatera Utara-Medan, Indonesia. \\ ${ }^{3}$ Agriculture Department, Universitas Mentodist Indonesia-Medan, Indonesia. \\ ${ }^{4}$ Nanomedicine Center, Universitas Sumatera Utara-Medan, Indonesia. \\ ${ }^{*}$ Corresponding author E-mail: riksonsiburian2000@yahoo.com
}

http://dx.doi.org/10.13005/ojc/3404035

(Received: June 06, 2018; Accepted: July 11, 2018)

\begin{abstract}
In this paper, we reported about the facile method to generate N-Graphene Nano Sheets (N-GNS) on room temperature. The purposes of this research are to synthesize and characterize $\mathrm{N}-$ GNS. This research used the modified Hummers's method to generate GNS and doping nitrogen to $\mathrm{N}$-GNS used ammonia $10 \mathrm{M}$ at $\mathrm{T}=30^{\circ} \mathrm{C}$. The $\mathrm{N}$-GNS was characterized by using XRD, FTIR and SEM-EDX. The XRD data show that $\mathrm{N}$ atoms was well be deposited on GNS to form N-GNS, it was indicated by the broad and weak peak was appear at $2 \theta=26.3^{\circ}$. This data is consistent with SEM-EDX, where the $\mathrm{N}$ atoms content on N-GNS is $2.72 \%$. FTIR data also defenitely confirm that there is interaction between $\mathrm{C}$ and $\mathrm{N}$, indicating by the peak is appear at $1396 \mathrm{~cm}^{-1}$. All of data show that the $\mathrm{N}$ is exist on GNS, it probes N-GNS may synthesized by facile method on room temperature.
\end{abstract}

Keywords: N-Graphene Nano Sheets, Graphene Nano Sheets, Ammonia, Room Temperature.

\section{INTRODUCTION}

Recently, graphene has been a widely material to develope and fascinate to research by various fields of science namely physics, chemistry, biology and material engineering. Basically, graphene is a carbon allotropy that becomes the basic structure in the formation of carbon-based materials such as graphite, carbon nano tube and fullerene ${ }^{1}$. Graphene is a carbon $2 \mathrm{D}$ that it may consist of one, several (2 - 9 layers) or multiple layers $(\geq 10 \text { layers })^{2}$. The graphene has the extraordinary properties which we never find them on the others carbon material, those are large surfaces area ${ }^{3,4}$, high electron mobility ${ }^{5,6}$, Young's modulus $\sim 1.0 \mathrm{TPa}^{7}$, mechanical resistance ${ }^{8}$, high thermal properties ${ }^{9}$, large surface area $\left(2630 \mathrm{~m}^{2} \mathrm{~g}^{-1}\right)^{10}$, high conductivity $(5000 \mathrm{Wm}-1 \mathrm{~K}-1)^{11}$, the world's strongest material ${ }^{12,13}$, and low production $\operatorname{cost}^{14}$.

One of the most interesting properties of graphene is the arrangement of very regular and 
almost perfect carbon atoms. Each carbon atom of graphene layer has a $\pi$-orbital and $\sigma$-bonding ${ }^{15}$. Based on its unique nature, graphene has been widely used in various applications such as supercapacitors ${ }^{16}$, nanoelectronics, nanocomposites, batteries, hydrogen storing ${ }^{17,18}$, sensors ${ }^{19}$, solar panne ${ }^{20}$, and adsorbents ${ }^{21}$. However, graphene has weaknesses such as having strange ribbon structure, valence band $(\pi)$ and conduction $\left(\pi^{\star}\right)$ are not separated (linear) so that graphene has no energy gap (zero gap) and graphene without metal shows low activity. Therefore, the graphene need be modified so that its activity can be increased by means of deflecting the graphene structure (defect of graphene), defects in the graphene structure is an attempt to change the electronic structure and increase the activity of graphene, especially the transfer of electrons to and from grafena $^{22}$. Graphene defects can be performed using dopants such as nitrogen, sulfur, boron and hydrogen. Dopants with nitrogen (N-Graphene) cause the $\mathrm{N}$ atoms incorporation to carbon atoms and donate the electrons to $\pi$-graphene system, consequently the $\mathrm{N}$ atoms can change the local density state around the Fermi energy level of $\mathrm{N}-\mathrm{Graphene}^{23}$. Thus, the electronic performance and activity can be improved with N-Graphene ${ }^{24,25}$. $\mathrm{N}$-doping carbon exhibits increasing capacitance performance of the capacitors as well as improving electronic conductivity due to there are formation of variations of the $\mathrm{N}$-doping structure ${ }^{26}$. Modification of carbon materials especially with the use of nitrogen ( $\mathrm{N}$-carbon dopant) has been proposed as a metal-free electrode material ${ }^{27}$.

$\mathrm{N}$-graphene can be synthesized via direct incorporation of $\mathrm{N}-\mathrm{C}$ with combustion techniques at high temperatures28, solvotermal chemistry $\left(T=230-300^{\circ} \mathrm{C}\right)^{29}$, laser ablation method ${ }^{30}$ and chemical vapor deposition (CVD) ${ }^{31,32}$. Graphene serves as a precursor for $\mathrm{N}$-graphene. The $\mathrm{C}$ source can be produced from methane, ethylene, benzene and acetylene ${ }^{33}$ while the $\mathrm{N}$ source can be produced from imidazole, dimethyl formamide, ethylene diamin, and benzylamine Fe-phthalocyanine ${ }^{34}$. N-C can also be obtained via a method after dopant treatment ${ }^{35} \mathrm{ie}$ oxidizing carbon with ammonia which was efficiently used as a catalyst for fuel cells ${ }^{36}$. $\mathrm{N}$-graphene is more easily produced because $\mathrm{N}$ can open the graphene structure ${ }^{37}$. The extraordinary properties of $\mathrm{N}$-graphene are similar with graphene, ie, high conductivity and large surface $\operatorname{area}^{38}$ and catalyst activity is more stable than $\mathrm{Pt} / \mathrm{C}^{39}$. Therefore, we fascinate to produce $\mathrm{N}$-graphene on room temperature by grafting the graphene with ammonia solution to produce $\mathrm{N}$-graphene. The obtaining $\mathrm{N}$-graphene was characterized using XRD, FTIR, and SEM-EDX. We expect incorporation C-N will occur on $\mathrm{N}$-graphene which is expected to increase the activity of grafena ${ }^{40}$. In this paper, we succeed to synthesize N-GNS at room temperature, without ammonia gas and it was done with facile way.

\section{MATERIALS AND METHODS}

\section{Sample Preparation}

Graphite powder (carbon $98 \%$, ash $15 \%$ ), $\mathrm{H}_{2} \mathrm{SO}_{4}(95-97 \%)$ and $\mathrm{NaNO}_{3}$ were obtained from Merck, $\mathrm{KGaA}$. $\mathrm{KMnO}_{4}, \mathrm{H}_{2} \mathrm{O}_{2}(30 \%)$ and $\mathrm{NH}_{3}(25 \%)$ were purchased from Sigma-Aldrich.

\section{Synthesis of Graphene Nano Sheets}

$2 \mathrm{~g}$ of graphite was added with $2 \mathrm{~g} \mathrm{NaNO}_{3}$ and $150 \mathrm{ml} \mathrm{H}_{2} \mathrm{SO}_{4}(\mathrm{l})$, respectively. After that, its solution was stirred for $4 \mathrm{~h}$ in ice bath condition. The end of $4 \mathrm{~h}, 10 \mathrm{~g}$ of $\mathrm{KMnO}_{4}$ were added gradually into solution and stirred for 4 hours. We choosed $4 \mathrm{~h}$ base on the real experiment condition where all of graphite powder and $\mathrm{NaNO}_{3}$ have been well dispersed on $\mathrm{H}_{2} \mathrm{SO}_{4} 98 \%$. Then it was added $200 \mathrm{~mL}$ of $\mathrm{H}_{2} \mathrm{SO}_{4} 5 \%$ and $10 \mathrm{~mL} \mathrm{H}_{2} \mathrm{O}_{2} 30 \%$, stirred for $4 \mathrm{~h}$ respectively ${ }^{41}$. Subsequently, solution was centrifuged at $72,000 \mathrm{rpm}$ for $10 \mathrm{~min}$. and ultrasonication for $6 \mathrm{~h}$ producing a solution of graphene oxide. The resulting graphene oxide solution was divided into two parts, the first solution was dried with oven at $80^{\circ} \mathrm{C}$ to obtain the graphene oxide powder. The other solution was added with a $50 \mathrm{~mL}$ of $\mathrm{NH}_{3} 10 \mathrm{M}$ and stirred for $72 \mathrm{~h}$ filtered and dried at $80^{\circ} \mathrm{C}$ to generate graphene nanosheets powder.

\section{Synthesis of N-Graphene Nano Sheets}

Briefly, N-Graphene Nano Sheets (N-GNS) was synthesized follow as: GNS powder was added 10 $\mathrm{mL} \mathrm{NH} \mathrm{H}_{3} 10 \mathrm{M}$ and stirred for 4 hours. Then, the solution was filtered and dried at $80^{\circ} \mathrm{C}$ resulting N-GNS.

\section{Characterization}

All of samples (graphite, graphene oxide, GNS, cathode primary battery (commercial) and N-GNS) were characterized by using XRD, FTIR and 
SEM - EDX, respectively. X-ray diffraction (XRD) analysis used X-Ray Rigaku Smartlab 3 kW. Cu-Ka radiation $(1.540598 \AA$ ) was used to observe samples from 5 to $80^{\circ}$ of $2 \theta$ (degree), scanning speed $2 \%$ min. $44 \mathrm{kV}$, and $40 \mathrm{~mA}$ current. Fourier Transform Infra Red (FTIR) spectra were recorded on Shimadzu IR Prestige-21. All of FTIR spectra were recorded in the transmittance mode in the range of $4000-500 \mathrm{~cm}^{-1}$. SEM - EDX analysis used type of EM 30 COXEM with a voltage of $20,000 \mathrm{kV}$ with enlargement $100-4000$ times.

\section{RESULTS AND DISCUSSION}

\section{XRD Analysis}

X-ray diffraction (XRD) patterns of graphite, graphene oxide, GNS, cathode primary battery (commercial) and N-GNS were shown in Fig. 1. Cathode primary batttery was used as a reference in this study. It shows a sharp peak (C (002)) at $26.58^{\circ}$ $\left(d=3.34^{\circ}\right)$, indicating graphite ${ }^{42}$. Base on that data, cathode primary battery is containing graphite as a support material. N-GNS was synthesized with steps: i) Graphite was oxidized with hard acid and oxidation agent to form graphite oxide. It was followed with ultrasonication in order to stabilization the colloid into water, producing graphene oxide. The formation of graphene oxide is probed by the appearance of a broad and sharp peak at $9.35^{\circ}$, indicating graphite was oxidized43,44 (Fig. 1); ii) Reducing of graphene oxide by using $\mathrm{NH}_{3}$, generating GNS. It is confirmed by the broad and weak peak at $26.71^{\circ}(d=3.34 \AA)$ (Fig. 1). We can see that the spacing of d-spacing is changed; meaning the reduction process of oxide has been well proceed. The $2 \theta$ of graphene oxide shifts much more to right side when it was reduced with $\mathrm{NH}_{3}$ to form GNS. That is due to functional groups containing graphene oxide was well be reduced and the rearrangement of GNS 45 ; and iii) Dopant $\mathrm{NH}_{3}$ into graphene structure. The XRD pattern of N-GNS has diffraction a weak peak at $2 \theta$ $\left(26.24^{\circ}\right)$. Its peak is broader and weaker than GNS and grahene oxide ${ }^{46}$. Interestingly, $2 \theta$ of $\mathrm{N}$-GNS is shifter to right side than GNS, indicating probably incorporation N-C occurs. Generally, the doping of hetero atoms $(\mathrm{N})$ in graphene induces defective sites and destruction in the carbon lattice, resulting in $\mathrm{N}$-graphene having a low crystallinity and causing a small change in the $2 \theta$ value $^{47}$.

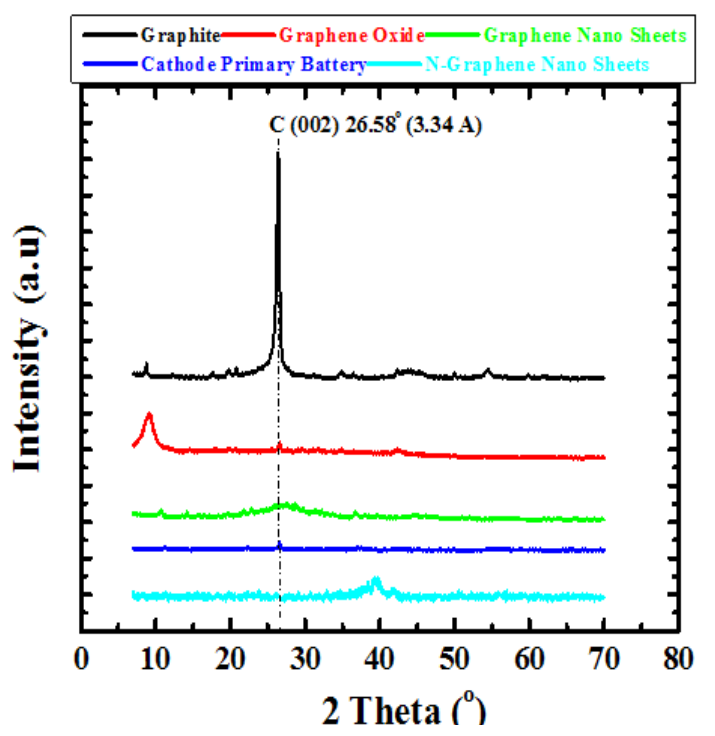

Fig. 1. XRD patterns of Cathode primary battery (commercial), Graphite, Graphene Oxide, Graphene Nano Sheets, Cathode primary battery (commercial) and N-Graphene Nano Sheets

Figure 1 shows that the $\mathrm{N}-\mathrm{GNS}$ have a peak at $2 \theta=26.16^{\circ}(d=3.39 \AA)$. It is very different compare to GNS, appearing a peak at $2 \theta=26.64^{\circ}$. Base on XRD data, it is clearly may be seen that $\mathrm{N}$-GNS was formed.

\section{FTIR Analysis}

In order to know the functional group containing on graphene oxide and each of interaction $\mathrm{C}-\mathrm{C}, \mathrm{C}=\mathrm{C}, \mathrm{C}-\mathrm{N}, \mathrm{C}=\mathrm{O}$, and $\mathrm{C}=\mathrm{C}$ aromatic of graphite, GNS and N-GNS, we used FTIR data. The FTIR spectra of battery primary's cathodes and commercial graphite show characteristic peaks at 1573 and $2337 \mathrm{~cm}^{-1}$, indicating vibration strain of $\mathrm{C}=\mathrm{C}$ aromatic. $\mathrm{A}$ wide peak at a wavelength of $3000-3700 \mathrm{~cm}^{-1}$ and a sharp peak at $1635 \mathrm{~cm}^{-1}$ appear on graphene oxide (Fig. 2), corresponding to the vibration of stretching and bending of the water molecule's $\mathrm{O}-\mathrm{H}$ bond ${ }^{48}$. The vibration peak around $1700 \mathrm{~cm}^{-1}$ corresponds to the $\mathrm{C}=\mathrm{O}$ bond of carboxyl group located on the edge of the GO layer. The strong intensity peak of about $1600 \mathrm{~cm}^{-1}$ shows vibration of strain $\mathrm{C}=\mathrm{C}$ on benzene ring or vibration deformation in $\mathrm{O}-\mathrm{H}$ band of intercalated water molecule ${ }^{49}$. The oxidation of graphite, resulting graphene oxide may be indicated by appearing the peak at $1325 \mathrm{~cm}^{-1}$ (C-OH bonding). In addition, peaks of 1203 and $1050 \mathrm{~cm}^{-1}$ show the deformations of epoxy vibration, and alcoxy, respectively ${ }^{50}$. 


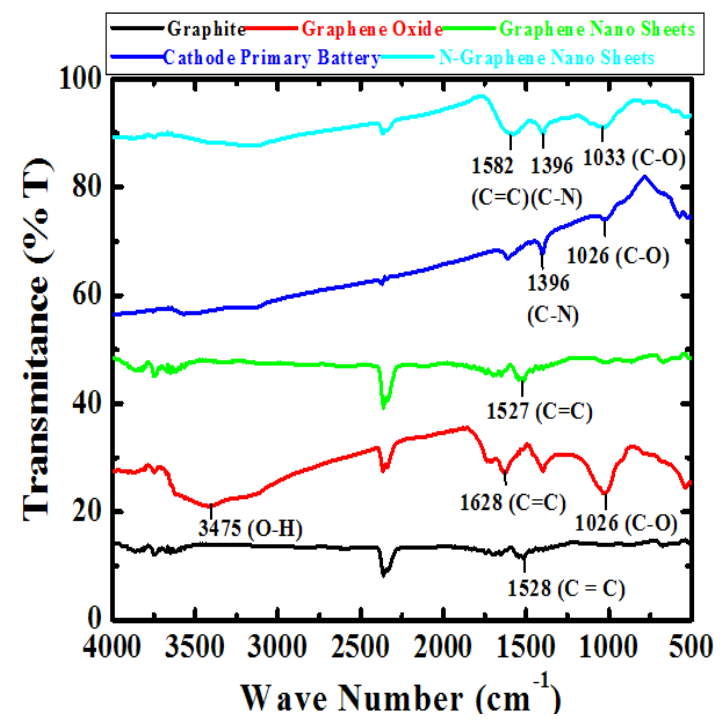

Fig. 2. FTIR data of Cathode primary battery (commercial), Graphite, Graphene Oxide, Graphene Nano Sheets, Cathode primary battery (commercial) and N-Graphene Nano Sheets

At GNS, it appears that there is an $\mathrm{O}-\mathrm{H}$ bond due to residual water content and $\mathrm{C}=\mathrm{C}$ aromatic which is the main bond in the structure of GNS. The extending time of ultrasonication, it may cause $\mathrm{C}=\mathrm{C}$ aromatic bond becomes stronger, while the bonds $\mathrm{C}=\mathrm{O}$ (carbonyl), $\mathrm{C}-\mathrm{OH}$ (phenol) and $\mathrm{C}-\mathrm{O}$ (alcoxy/ ether) will decrease. This indicates that the reduction of graphene oxide to be GNS is well formed. However, there is a peak at $2300 \mathrm{~cm}^{-1}$ in GNS due to the presence of the $\mathrm{O}=\mathrm{C}=\mathrm{O}$ bond. This functional group is not a component of GNS, it is probably $\mathrm{CO}_{2}$ gas of air which is attached to the GNS surface. Interestingly, there are peaks at 1396 and $1573 \mathrm{~cm}^{-1}$, corresponding to the strong and sharp $\mathrm{C}-\mathrm{N}$ and $\mathrm{C}=\mathrm{C}$ bonds respectively. It means nitrogen atoms may incorporate with carbon atoms at N-GNS. Therefore, N-GNS may be produced ${ }^{51}$.

\section{SEM-EDX Analysis}

The surfaces and composition of GNS may be supported by using SEM-EDX. The SEM images of GNS are shown in Fig. 3. It is provided with three magnifications. GNS has random surfaces (Fig. 3A), small pores and wrinkle surfaces (Fig. 3B). Based on the results of SEM data, GNS has not been a single layers, it can be seen at Fig. 3C), indicating its surfaces are still more smooth coalesce, some of them are thin and uniform surfaces.

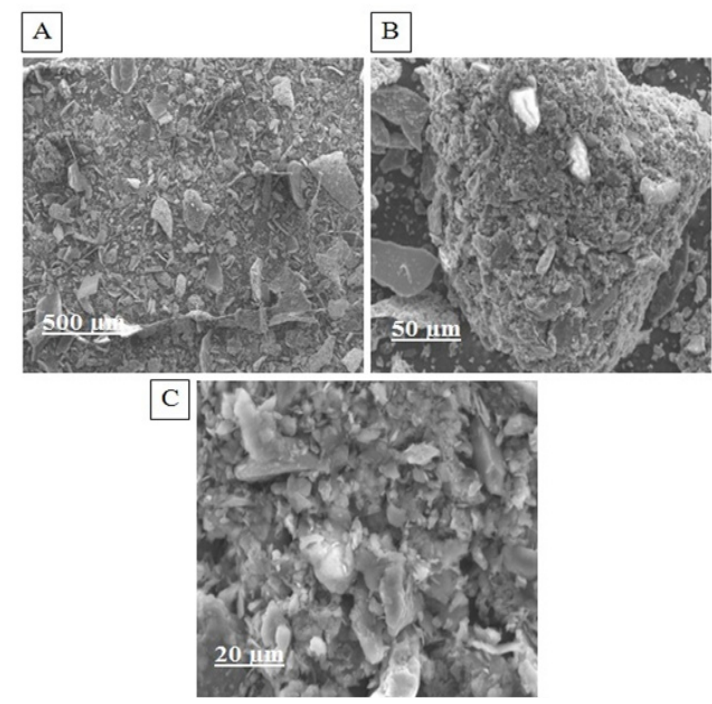

Fig. 3. SEM images of GNS with magnification (A) 100x, (B) $1000 \times$ and $(C) 4000 \times$ magnification

The composition chemical of GNS was characterized by using Energy Dispersive X-Ray (EDX). The EDX data is shown in Table 1.

Table 1: The results of EDX analyses for GNS

\begin{tabular}{cccc}
\hline $\begin{array}{c}\text { Number } \\
\text { Element }\end{array}$ & $\begin{array}{c}\text { Element } \\
\text { Symbol }\end{array}$ & $\begin{array}{c}\text { Element } \\
\text { Name }\end{array}$ & $\begin{array}{c}\text { Element } \\
\text { Weight(\%) }\end{array}$ \\
\hline 6 & $\mathrm{C}$ & Carbon & 53.14 \\
8 & $\mathrm{O}$ & Oxygen & 36.88 \\
& Sum & & 100.00 \\
\hline
\end{tabular}

Table 1 show that GNS has $\mathrm{C}$ atom as a dominant element, meaning GNS structure consists of carbon atomic bonds. However, GNS still contains oxygen $(\mathrm{O})$.

N-GNS shows a uniform surface with a thinner layer than GNS (Fig. 4A) and it has a small pore size and wrinkled surface (Fig. $4 B$ and $C$ ). It means the morphology of N-GNS is totally different with GNS.

Interestingly, EDX data shows that $\mathrm{N}$ atoms exist into $\mathrm{N}-\mathrm{GNS}$, it means there is incorporation between $\mathrm{C}$ and $\mathrm{N}$ on $\mathrm{N}$-GNS as well as $\mathrm{N}$-dopant effect (Table 2).

Table 2 shows there are $2.72 \% \mathrm{~N}$ atoms in N-GNS. That is caused $\mathrm{N}$ atoms incorporate with carbon atoms. It is possible because $\mathrm{N}$ may donate its electrons to the $\pi$-graphene system ${ }^{52}$. 


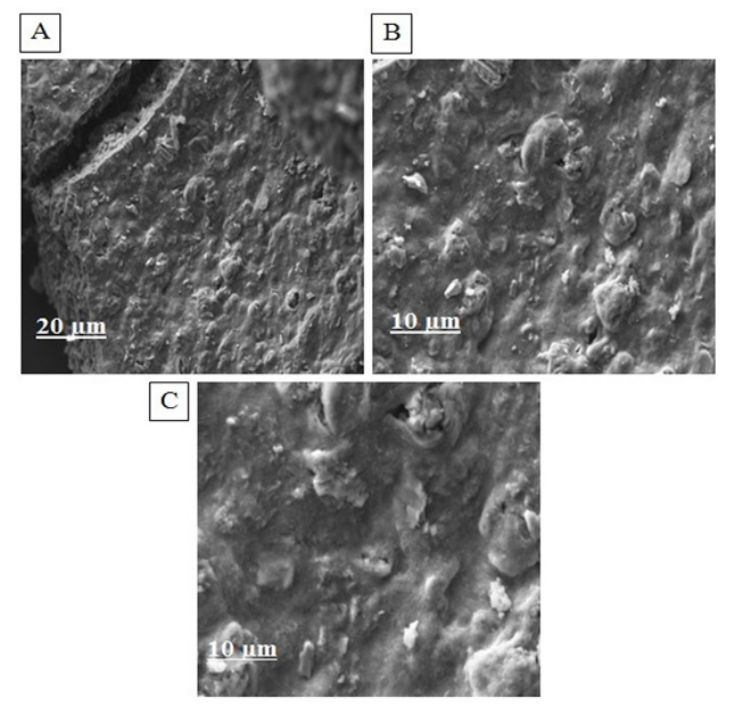

Fig. 4. SEM image of N-GNS with magnification (A) 500x, (B) $1000 \times$ and $(C) 4000 \times$ magnification

\section{CONCLUSION}

$\mathrm{N}-$ GNS may be produced base on graphite as a raw material under conditions room temperature
Table 2: The results of EDX analyses for N-GNS

\begin{tabular}{cccc}
\hline $\begin{array}{c}\text { Number } \\
\text { Element }\end{array}$ & $\begin{array}{c}\text { Element } \\
\text { Symbol }\end{array}$ & $\begin{array}{c}\text { Element } \\
\text { Name }\end{array}$ & $\begin{array}{c}\text { Element } \\
\text { Weight (\%) }\end{array}$ \\
\hline 6 & $\mathrm{C}$ & Carbon & 61.07 \\
8 & $\mathrm{O}$ & Oxygen & 36.21 \\
7 & $\mathrm{~N}$ & Nitrogen & 2.72 \\
& Sum & & 100.00 \\
\hline
\end{tabular}

and usage ammonia solution. It may role both as a reducing agent and may be nitrogen atoms source.

\section{ACKNOWLEDGEMENT}

We would like to thankful for "Direktorat Jenderal Penguatan Riset dan Pengembangan", Ministry of Research, Technology and Higher Education, Republic of Indonesia, No. SP DIPA - 042.06.1.401516/2018, 5 December 2017 who funding supported on our research. We also would like to thankful for Labsystematic - Jakarta, Indonesia who supported us for SEM - EDX analysis.

\section{REFERENCES}

1. Basu, S.; Bhattacharyya, P. Chemical., 2012, 173, $1-21$.

2. Ambrosi, A.; Chua, C. K.; Bonanni, A.; Martin, P. Chemical Reviews., 2014, 114, 7150 - 7188.

3. Choi, J. Y.; Higgins, D.; Chen, Z. Journal of the Electrochemical Society., 2012, 159, B86 - B89.

4. Luo, C.; Xie, H.; Wang, Q.; Luo, G.; Liu, C. Journal of Nanomaterials., 2015, 185,1 - 10.

5. Novoselov, K. S.; Geim, A. K.; Geim, S. V.; Morozov, D.; Jiang, Y.; Zhang, S. V.; Dubonos, I. A.; Grigorieva, A. F. Science., 2004, 306, 666-669.

6. Novoselov, K. S.; Geim, A. K. Science., 2007, $6,183-188$.

7. Lee, C.; Wei, X.; Kysar, J. W.; Hone, J. Science., 2008, 321, 386 - 388.

8. Lee, C.; Wei, X.; Kysar, J. W.; Hone, J. Science., 2008, 321, 385 - 388.

9. Balandin, A. A.; Ghosh, S.; Bao, W.; Calizo, I.; Teweldebrhan, D.; Miao, F.; Lau, C. N. Nano Lett., 2008, 8, 902 - 907.

10. Stoller, M. D.; Park, S. Y.; Zhu, J.; Ruoff, R. S. Nano Lett., 2008, 8, 3498 - 3502.

11. Baladin. Nano Letters., 2008, 8, 902 - 907.

12. Zhang, Y.; Tan, Y. W.; Stormer, H. L.; Kim, P.
Nature., 2005, 438, 201 - 204.

13. Zhang, Y.; Small, J. P.; Amori, M. E. S, Kim P. Phys. Rev. Lett., 2005, 94, 776 - 803.

14. Samulskiet. Chem. Mater., 2008, 20, 6792-6797.

15. Terrones A. R.; Botello-Mendez, A. R.; Campos-Delgado, J.; Lopez-Urias, F.; VegaCantu, Y. I, Rodriguez-Macias, F. J.; Elias, A. L.; Munoz-Sandoval, E.; Cano-Marquez, A. G.; Charlier, J.; Terrones, H. Nano Today., 2010, 5, 351 - 372.

16. Stoller, M. D.; Park, S. Y.; Zhu, J.; Ruoff, R. S. Nano Lett., 2008, 8, 3498 - 3502.

17. Geim, A. K.; Novoselov, K. S. Nature Materials., 2007, 6, $183-191$.

18. Wu, J.; Pisula, W.; Müllen, K. Chem. Rev., 2007, 107, 718.

19. Ang, P. K.; Chen, W.; Wee, A. T.; Loh, K. P. J. Am. Chem. Soc., 2008, 130, 14392 - 14393.

20. Wang, X.; Zhi, L.; Mullen, K. Nano Lett., 2008, $8,323-327$.

21. Xu, J.; Wang, L.; Zhu, Y. Langmuir., 2012, 28, 8418 - 8425 .

22. Tan, C.; Rodríguez-Lopez, J.; Parks, J. J.; Ritzert, N. L.; Ralph, D. C.; Abruna, H. D. ACS Nano., 2012, 6, 3070. 
23. Wang, L.; Li, H. IEEE Trans. Ind. Appl., 2010, 46, 1011.

24. Bostwick, A.; Speck, F.; Seyller, T.; Horn, K.; Polini, M.; Asgari, R.; MacDonald, A.H.; Rotenberg, E. Science., 2010, 328, 999-1002.

25. Wei, Q.; Tong, X.; Zhang, G.; Qiao, J.; Gong, Q.; Sun, S. Catalysts., 2015, 5, $1574-1602$.

26. Seger, B.; Kamat, V. P. J. Phys. Chem. C., 2009, 19, $7990-7995$.

27. Stankovich, S.; Dikin, D. A.; Piner, R. D.; Kohlhaas, K. A.; Kleinhammes, A.; Jia, Y.; Wu, Y.; Nguyen, S. T.; Ruoff, R. S. Carbon., 2007, 10, $1558-1565$.

28. Sun, M.; Liu, H.; Liu, Y.; Qu, J.,; Li, J. Nanoscale., 2015, 7, $1250-1269$.

29. Chen, L.; Xia, K.; Huang, L.; Li, L.; Pei, L.; Fei, S. Int. J. Hydrogen Energy., 2013, 38, $3297-3303$.

30. Du, Z.; Wang, S.; Kong, C.; Deng, Q.; Wang, G.; Liang, C.; Tang, H. J. Solid State Electrochem., 2015, 19, 1541 - 1549.

31. Guo, Q.; Zhao, D.; Liu, S.; Chen, S.; Hanif, M.; Hou, H. Electrochim. Acta., 2014, 138, $318-324$.

32. She, X.;Yang, D.; Jing, D.; Yuan, F.;Yang, W.; Guo, L.; Che, Y. Nanoscale., 2014, 6, 11057 - 11061.

33. Wang, Y.; Cui, X.; Li, Y.; Chen, L.; Chen, H.;Zhang, L.; Shi, J. A. Carbon., 2014, 68, $232-239$.

34. Rao, C. V.; Ishikawa, Y. J. Phys. Chem. C., 2012, 116, $4340-4346$.

35. Chan, L. H.; Hong, K. H.; Xiao, D. Q.; Lin, T. C.; Lai, S. H.; Hsieh, W. J.; Shih, H. C. Phys. Rev. B., 2004, 70, 125408.

36. Vikkisk, M.; Kruusenberg, I.; Ratso, S.; Joost, U.; Shulga, E.; Kink, I.; Rauwel, P.; Tammeveski, K. RSC Adv., 2015, 5, 59495 - 59505.

37. Wood, K. N.; O'Hayre, R.; Pylypenko, S.
Energy Environ. Sci., 2014, 7, 1212 - 1249.

38. Qu, L.; Liu,Y.; Baek, J. B.; Dai, L. ACS Nano., 2010, 4, 1321.

39. Feng, L. Y.; Chen, Y. G.; Chen, L. ACS Nano., 2011, 5, $9611-9618$.

40. Xin, Y.; Liu, J.; Zhou, Y.; Liu, W.; Gao, J.; Xie, Y,; Yin, Y.; Zou, Z. J. Power Sources., 2011, 196, 1012 - 1018.

41. Hummers, W.S. J.Am. Chem. Soc., 1958, 80, 1339.

42. Huang, N. International Journal of Nanomedicine., 2011, 6, 3125-3137.

43. Jeong, K. H.; Lee, P. Y.; Lahaye, R. J. W. E.; Park, H. M.; An, K. H.; Kim, I. J. J Am Chem Soc., 2008, 130, $1362-1366$.

44. Shao, G. Journal of Materials Science., 2012, 47, $4400-4409$

45. Siburian, R; Nakamura, J. The Journal of Physical Chemistry C., 2012, 116, 22947 - 22953.

46. Liu, Z.; Zhang, G.; Lu, Z.; Jin, X.; Chang, Z. Nano Research., 2013, 6, $293-301$.

47. Geng, D.; Yang, S.; Zhang, Y.; Yang, J.; Liu, J.; Li, R. Applied Surface Science., 2011, 257, $9193-9198$.

48. Chae, D. H.; Utikal, T.; Weisenburger, S.; Giessen, H.; von Klitzing, K.; Lippitz, M. Nano Lett., 2011, 11, 1379.

49. Shao, G. Journal of Materials Science., 2012, 47, $4400-4409$

50. Avinav, G.; Nandgaonkar.; Wang, Q.; Fu, K.; Krause, W. K. A. Green Chem., 2014, 16, $3195-3201$.

51. Acik, M.; Lee, G.; Mattevi, C.; Pirkle, A.; Wallace, R. M.; Chhowalla, M.; Cho, K.; Chabal, Y., J. Phys. Chem. C., 2011, 115, $19761-19781$.

52. Siburian, R.;Sebayang, K.; Supeno, M.;Marpaung. Chemistry Select., 2017, 2, 1188 - 1195. 